\title{
Analysis of expression levels of IL-17 and IL-34 and influencing factors for prognosis in patients with lupus nephritis
}

\author{
YANNA CHENG $^{1 *}$, XIAOJUAN YANG $^{1 *}, \mathrm{XIJUN} \mathrm{ZHANG}^{2}$ and $\mathrm{ZHI} \mathrm{AN}^{1}$ \\ ${ }^{1}$ Department of Nephrology, Yanan University Affiliated Hospital; \\ ${ }^{2}$ Department of Nephrology, Yanan People's Hospital, Yanan, Shaanxi 716000, P.R. China
}

Received June 11, 2018; Accepted January 2, 2019

DOI: $10.3892 /$ etm.2019.7168

\begin{abstract}
Expression levels of interleukin-17 (IL-17) and IL-34 was investigated to analyze the influencing factors for prognosis in patients with lupus nephritis (LN). Clinical data of 45 patients (LN group) treated and diagnosed with LN via renal biopsy in Yanan University Affiliated Hospital from October 2010 to October 2012 and 50 healthy subjects (control group) were analyzed retrospectively. Levels of serum IL-17 and IL-34 were detected via enzyme-linked immunosorbent assay. Correlations of serum IL-17 and IL-34 with urinary protein in LN patients were analyzed via Pearson correlation analysis. Univariate survival analysis was performed using the Kaplan-Meier method, and multivariate analysis was performed for LN prognosis using the Cox proportional hazards model. Levels of serum IL-34 and IL-17 in patients in LN group were significantly higher than those in control group $(\mathrm{P}<0.001)$. Serum IL-17 and IL-34 in LN patients were positively correlated with urinary protein $(r=0.436$ and $0.714, \mathrm{P}<0.05)$. Adverse factors affecting the prognosis of $45 \mathrm{LN}$ patients including age, hemoglobin, platelet, blood uric acid, urinary protein, IL-17 and IL-34, showing statistically significant differences $(\mathrm{P}<0.05)$. Age, hemoglobin, blood uric acid, urinary protein, IL-17 and IL-34 were independent risk factors for poor prognosis of $\mathrm{LN}(\mathrm{P}<0.05)$. The inflammatory factors IL-17 and IL-34 are highly expressed in the serum of LN patients. Levels of serum IL-17 and IL-34 in LN patients have positive correlations with urinary protein. Results of univariate and multivariate Cox regression analyses reveal that age, hemoglobin, blood uric acid, urinary protein, IL-17 and IL-34 are independent risk factors for poor prognosis of LN. IL-17 and IL-34 can therefore serve as effective indexes for clinical diagnosis, treatment and prognosis of LN.
\end{abstract}

Correspondence to: Dr Zhi An, Department of Nephrology, Yanan University Affiliated Hospital, 43 Beida Street, Yanan, Shaanxi 716000, P.R. China

E-mail: aq36uy@163.com; 2879119948@qq.com

*Contributed equally

Key words: lupus nephritis, IL-17, IL-34, influencing factors for prognosis

\section{Introduction}

Systemic lupus erythematosus (SLE) is a kind of diffuse connective tissue disease (1), usually involving the whole body. The course and number of affected organs of SLE are negatively correlated with its prognosis (2). The morbidity and mortality rates of lupus nephritis (LN) account for approximately $60 \%$ in SLE $(3,4)$. The pathogenesis of LN remains unclear currently, which, according to the literature, may be caused by interaction of factors such as environment, heredity, autoimmunity and estrogen $(5,6)$. LN is characterized by a high prevalence rate and long treatment cycle, and it leads to death in severe cases (7). Therefore, the diagnosis of LN is of great significance in providing a basis for clinical treatment and prognosis.

Interleukin-34 (IL-34) is an inflammatory factor, another major ligand of colony-stimulating factor-1 receptor (CSF-1R) following CSF-1, which can directly bind to CSF-1R to exert similar and independent biological effects of CSF-1 (8). IL-34, mainly through binding to CSF-R, regulates the activation, survival, proliferation, chemotaxis and secretion of corresponding cytokines in monocytes or macrophages (9). Inflammatory injury mediated by macrophages plays an important role in the pathogenesis of LN (10). IL-17 is an inflammatory factor with important effects in autoimmune diseases, pro-inflammatory and organ transplant rejection reactions (11). IL-17 can bind to the corresponding receptors to result in the infiltration of inflammatory cells and tissue damage (12). According to the literature, IL-17 can promote the progression of SLE, which is highly expressed in serum of SLE patients and animal model of lupus (13).

This study investigated the expression levels of serum IL-17 and IL-34 and analyze the influencing factors for prognosis in LN patients. Results showed IL-17 and IL-34 are independent risk factors for poor prognosis of $\mathrm{LN}$. The findings provide a theoretical basis for the diagnosis, treatment and prognosis of $\mathrm{LN}$ in the future.

\section{Materials and methods}

General data. A total of 45 patients treated and diagnosed with LN via renal biopsy in Yanan University Affiliated Hospital (Yanan, China) from October 2010 to October 2012 were selected as LN group, including 8 males and 37 females 
Table I. General data.

\begin{tabular}{|c|c|c|c|c|}
\hline Factor & LN group $(n=45)$ & Control group $(\mathrm{n}=50)$ & $\mathrm{t} / \chi^{2}$ value & P-value \\
\hline Age (years) & $42.08 \pm 16.52$ & $41.28 \pm 15.85$ & 0.241 & 0.810 \\
\hline $\operatorname{Sex}[\mathrm{n}(\%)]$ & & & 0.800 & 0.076 \\
\hline Male & $8(17.78)$ & $10(20.00)$ & & \\
\hline Female & $37(82.22)$ & $40(80.00)$ & & \\
\hline Leukocyte $\left(\times 10^{9}\right)$ & $6.34 \pm 0.45$ & $5.98 \pm 0.84$ & 2.562 & 0.012 \\
\hline Hemoglobin $(\mathrm{g} / \mathrm{l})$ & $110.86 \pm 15.25$ & $137.94 \pm 14.28$ & 8.937 & $<0.001$ \\
\hline Blood albumin $(\mathrm{g} / \mathrm{l})$ & $30.85 \pm 7.46$ & $46.52 \pm 2.48$ & 14.020 & $<0.001$ \\
\hline Blood platelet $\left(\times 10^{9} / 1\right)$ & $232.94 \pm 52.05$ & $257.76 \pm 53.49$ & 0.287 & 0.025 \\
\hline Blood uric acid (mmol/l) & $374.26 \pm 82.45$ & $300.15 \pm 52.34$ & 5.284 & $<0.001$ \\
\hline Serum creatinine $(\mu \mathrm{mol} / \mathrm{l})$ & $64.15 \pm 20.54$ & $53.14 \pm 7.53$ & 3.537 & $<0.001$ \\
\hline Systolic pressure $(\mathrm{mmHg})$ & $128.82 \pm 9.46$ & $123.92 \pm 8.45$ & 2.667 & 0.009 \\
\hline Diastolic pressure $(\mathrm{mmHg})$ & $81.46 \pm 8.24$ & $77.46 \pm 6.82$ & 2.587 & 0.011 \\
\hline Urinary protein (g) & $2.79 \pm 2.14$ & $0.12 \pm 0.02$ & 8.827 & $<0.001$ \\
\hline Triglyceride $(\mathrm{mmol} / \mathrm{l})$ & $2.43 \pm 1.25$ & $1.43 \pm 0.72$ & 4.837 & $<0.001$ \\
\hline
\end{tabular}

with an average age of $42.08 \pm 16.52$ years. Another 50 healthy subjects, including 10 males and 40 females with an average age of $41.28 \pm 15.85$ years, undergoing physical examination during the same period were selected as the control group. There were no significant differences in age and sex between the two groups $(\mathrm{P}>0.05)$, while leukocyte, hemoglobin, blood albumin, blood platelet, blood uric acid, serum creatinine, systolic pressure, diastolic pressure, urinary protein and triglyceride had statistically significant differences $(\mathrm{P}<0.05)$. None of the patients had undergone treatment with hormones and immunosuppressors in the prior 3 months. Pregnant or breastfeeding patients, or patients with autoimmune diseases, severe infection, other kidney-related diseases or rheumatoid arthritis were excluded.

The study was approved by the Ethics Committee of Yanan University Affiliated Hospital (Yanan, China). All the patients, or their families, signed the informed consent, and the patients had complete clinical data. General patient information is shown in Table I.

Reagents and equipment. Human serum IL-17 and IL-34 enzyme-linked immunosorbent assay (ELISA) kits were purchased from Shanghai Lengton Biotechnology Co., Ltd., and Anthos PHOMO full-automatic microplate reader was purchased from Shanghai Zhongsheng Life Science Development Co., Ltd. (Shanghai, China).

Detection of $I L-17$ and $I L-34$. After $3 \mathrm{ml}$ fasting venous blood was drawn from the patients in the morning and centrifuged at 2,600 x g at $4^{\circ} \mathrm{C}$ for $10 \mathrm{~min}, 1 \mathrm{ml}$ serum was taken using a pipette for standby application. Levels of serum IL-17 and IL-34 were detected via ELISA. The kit and sample to be detected were taken from the refrigerator $30 \mathrm{~min}$ in advance to be balanced to the room temperature, and sample, standard and blank wells were set up. Enzyme-labeled reagents and samples were not added into blank well, $100 \mu \mathrm{l}$ samples to be detected or standard substances were added into the remaining wells and mixed evenly. Then the ELISA plate was covered with a membrane, followed by incubation at $37^{\circ} \mathrm{C}$ for $2 \mathrm{~h}$. After the liquid in each well was discarded and spun dry, each well was added with $100 \mu \mathrm{l}$ working solution $\mathrm{A}$ and covered with the membrane, followed by incubation at $37^{\circ} \mathrm{C}$ for $1 \mathrm{~h}$. After the liquid in each well was discarded and spun dry, the plate was washed 3 times, and each well was added with $100 \mu$ l working solution $\mathrm{B}$ and covered with the membrane, followed by incubation at $37^{\circ} \mathrm{C}$ for $1 \mathrm{~h}$. After the liquid in each well was discarded and spun dry, the plate was washed again 3 times, each well was added with $90 \mu \mathrm{l}$ substrate solution and covered with the membrane, followed by color development in the dark at room temperature for $20 \mathrm{~min}$. Stop solution $(50 \mu \mathrm{l})$ was added to each well, and the optical density (OD) of each well was detected at a wavelength of $450 \mathrm{~nm}$ using the microplate reader. Finally, the IL-34 and IL-17 concentrations were calculated.

Statistical analysis. Statistical Product and Service Solutions (SPSS) 17.0 software (Shanghai Cabit Information Technology Co., Ltd.) was used for analysis. Chi-square test was used for enumeration data, and t-test was used for measurement data. Univariate survival analysis was performed using the Kaplan-Meier method and log-rank test, and univariate and multivariate analyses were performed using the Cox proportional hazards model. $\mathrm{P}<0.05$ was considered to indicate a statistically significant difference.

\section{Results}

Comparison of serum IL-17 and IL-34 levels between the two groups. Levels of serum IL-17 and IL-34 in patients in LN group were significantly higher than those in control group, and there were statistically significant differences $(\mathrm{P}<0.001)$ (Fig. 1 and Table II).

Correlation analysis of IL-17 and IL-34 with urinary protein in $L N$. Serum IL-17 and IL-34 in LN patients were positively correlated with urinary protein $(\mathrm{r}=0.436$ and $0.714, \mathrm{P}<0.05)$ (Table III). 
Table II. Comparison of serum IL-34 and IL-17 levels between the two groups.

\begin{tabular}{lccrc}
\hline Index & LN group & Control group & t value & P-value \\
\hline No. & 45 & 50 & & \\
IL-34 (ng/l) & $57.61 \pm 16.24$ & $22.34 \pm 11.53$ & 12.300 & $<0.001$ \\
IL-17 (ng/l) & $40.82 \pm 24.15$ & $14.94 \pm 4.86$ & 7.417 & $<0.001$ \\
\hline
\end{tabular}

Table III. Correlation analysis of IL-34 and IL-17 with urinary protein in LN.

\begin{tabular}{lccc}
\hline Item & IL-34 & IL-17 & P-value \\
\hline Urinary protein & 0.714 & 0.436 & $\mathrm{P}<0.05$ \\
\hline
\end{tabular}

Analysis of influencing factors for survival time of LN patients. The 3- and 5-year overall survival rates of LN patients were 86.42 and $74.67 \%$, respectively. Influencing factors for survival time of $45 \mathrm{LN}$ patients were analyzed via univariate analysis, and results manifested that adverse factors affecting the prognosis of LN patients included age, hemoglobin, platelet, blood uric acid, urinary protein, IL-17 and IL-34, displaying statistically significant differences $(\mathrm{P}<0.05)$. According to results of multivariate Cox regression analysis, age, hemoglobin, blood uric acid, urinary protein, IL-17 and IL-34 were independent risk factors for the poor prognosis of $\mathrm{LN}$, and differences were statistically significant $(\mathrm{P}<0.05)$ (Tables IV and V).

\section{Discussion}

Lupus nephritis is a chronic disease that often relapses and remits alternately. Renal injury is aggravated continuously in the acute phase, thus accelerating the progression of end-stage

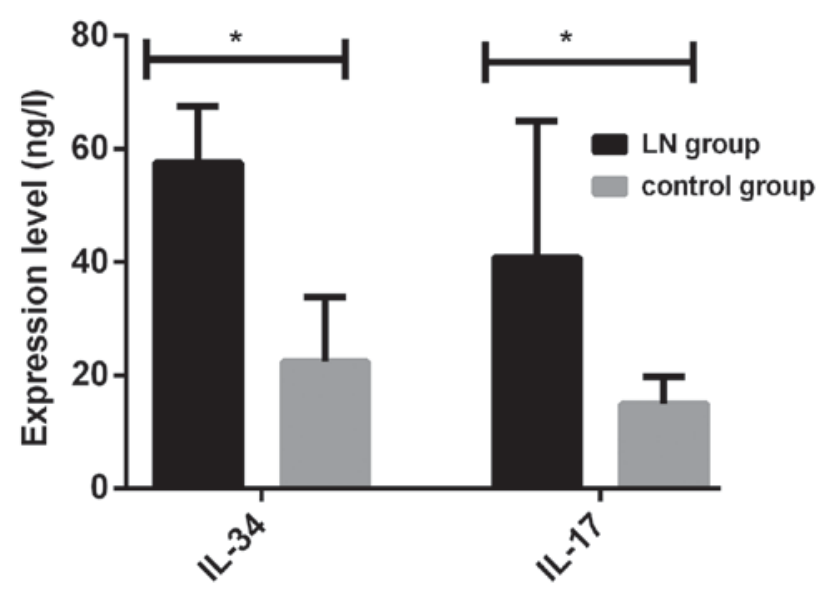

Figure 1. Comparison of serum levels of IL-34 and IL-17 in the two groups The serum levels of IL-34 and IL-17 in the lupus nephritis (LN) group were significantly higher than those in the control group. ${ }^{*} \mathrm{P}<0.001$.

renal disease of $\mathrm{LN}$ (14). The prevalence rate of end-stage renal disease is as low as $26 \%$, but the proportion of active lesions and relapse in $\mathrm{LN}$ is up to $27-66 \%$, leading to the increased mortality rate of LN (15). Currently, commonly used diagnostic methods for LN include decreased glomerular filtration rate, proteinuria and renal biopsy. However, renal biopsy has not been universally employed because it affects treatment and prognosis (16). Therefore, the early diagnosis, treatment and monitoring of progression of $\mathrm{LN}$ have become research hotspots, providing clues for the prognosis (17).

Results of this study revealed that the levels of serum IL-17 and IL-34 in patients in LN group were obviously higher than those in control group, showing statistically significant differences $(\mathrm{P}<0.001)$. Research results of Bethunaickan et al (18) and Susianti et al (19) are consistent with those in this study. Bethunaickan et al (18) showed that IL-34 messenger ribonucleic acid (mRNA) is highly expressed in the kidney of lupus mice and it is significant in the pathogenesis of LN.

Table IV. Univariate analysis results of prognosis of LN patients.

\begin{tabular}{|c|c|c|c|}
\hline Factors & P-value & $\begin{array}{l}\text { Hazard ratio } \\
\text { (HR) }\end{array}$ & $\begin{array}{l}95 \% \text { confidence interval } \\
(95 \% \mathrm{CI})\end{array}$ \\
\hline Sex (male vs. female) & 0.306 & 1.052 & $0.357-1.138$ \\
\hline Age ( $<40$ years vs. $\geq 40$ years $)$ & 0.008 & 0.035 & $0.018-0.052$ \\
\hline Leukocyte $\left(<6 \times 10^{9}\right.$ vs. $\left.\geq 6 \times 10^{9}\right)$ & 0.526 & 1.012 & $0.004-1.756$ \\
\hline Hemoglobin $(<123 \mathrm{~g} / \mathrm{l} \mathrm{vs} . \geq 123 \mathrm{~g} / \mathrm{l})$ & 0.004 & 0.047 & $0.032-0.069$ \\
\hline Blood albumin $(<38 \mathrm{~g} / \mathrm{l} \mathrm{vs} . \geq 38 \mathrm{~g} / \mathrm{l})$ & 0.852 & 2.121 & $0.104-4.265$ \\
\hline Blood platelet $\left(<244 \times 10^{9} / 1 \mathrm{vs} . \geq 244 \times 10^{9} / 1\right)$ & 0.035 & 0.462 & $0.254-0.672$ \\
\hline Blood uric acid (<337 mmol/l vs. $\geq 337 \mathrm{mmol} / \mathrm{l})$ & $<0.001$ & 3.026 & $1.389-4.258$ \\
\hline Serum creatinine $(<58 \mu \mathrm{mol} / 1 \mathrm{vs} . \geq 58 \mu \mathrm{mol} / \mathrm{l})$ & 0.418 & 0.627 & $0.237-2.467$ \\
\hline Systolic pressure (<126 mmHg vs. $\geq 126 \mathrm{mmHg}$ ) & 0.691 & 0.508 & $0.118-0.964$ \\
\hline Diastolic pressure ( $<79 \mathrm{mmHg}$ vs. $\geq 79 \mathrm{mmHg}$ ) & 0.483 & 0.620 & $0.004-2.586$ \\
\hline Urinary protein (<1 g vs. $\geq 1 \mathrm{~g})$ & $<0.001$ & 2.895 & $0.623-4.953$ \\
\hline Triglyceride $(<2 \mathrm{mmol} / \mathrm{l} \mathrm{vs} . \geq 2 \mathrm{mmol} / \mathrm{l})$ & 1.462 & 0.743 & $0.372-2.561$ \\
\hline IL-34 (<55.37 ng/l vs. $\geq 55.37$ ng/l) & $<0.001$ & 2.865 & $1.423-4.824$ \\
\hline IL-17 (<42.62 ng/l vs. $\geq 42.62$ ng/l) & $<0.001$ & 2.541 & $1.147-3.749$ \\
\hline
\end{tabular}


Table V. Multivariate analysis results of prognosis of LN patients.

\begin{tabular}{|c|c|c|c|}
\hline Factors & P-value & HR & $95 \% \mathrm{CI}$ \\
\hline Age ( $<40$ years vs. $\geq 40$ years $)$ & 0.036 & 1.624 & $1.306-3.251$ \\
\hline Hemoglobin $(<123$ g/l vs. $\geq 123$ g/l) & 0.021 & 0.429 & $0.284-0.672$ \\
\hline Blood platelet $\left(<244 \times 10^{9} / 1\right.$ vs. $\left.\geq 244 \times 10^{9} / 1\right)$ & 0.082 & 1.327 & $0.876-2.728$ \\
\hline Blood uric acid $(<337 \mathrm{mmol} / \mathrm{l} \mathrm{vs} . \geq 337 \mathrm{mmol} / \mathrm{l})$ & 0.007 & 2.681 & $1.512-4.903$ \\
\hline Urinary protein (<1 g vs. $\geq 1 \mathrm{~g})$ & 0.010 & 2.546 & 2.014-4.865 \\
\hline IL-34 (<55.37 ng/l vs. $\geq 55.37 \mathrm{ng} / \mathrm{l})$ & 0.032 & 1.625 & $1.004-3.126$ \\
\hline IL-17 (<42.62 ng/l vs. $\geq 42.62$ ng/l) & 0.028 & 1.451 & $0.438-3.647$ \\
\hline
\end{tabular}

A possible reason is that the glomerular and renal interstitial damage is aggravated through damage to inflammatory factors. Susianti et al (19) found that the IL-17 level is significantly increased in LN. A possible reason is that IL-17 can promote other immune inflammatory mediators and epithelial cells, and make inflammatory cells accumulate and damage renal tissues, thereby leading to proteinuria. According to results of Pearson's correlation analysis, the levels of serum IL-34 and IL-17 in LN patients had positive correlations with urinary protein $(\mathrm{r}=0.714$ and $0.436, \mathrm{P}<0.05)$. There are few studies on the correlation between IL-17 and urinary protein, so the results in this study are not confirmed. Moreover, Menke et al (20) found that the IL-34 content in urine of LN mice is positively correlated with secretion of urinary albumin $(\mathrm{r}=0.915, \mathrm{P}<0.01)$, which is basically consistent with the results in this study. Therefore, IL-34 can display the activity degree of LN.

The 3- and 5-year overall survival rates of LN patients were 86.42 and $74.67 \%$, respectively. Influencing factors for survival time of $45 \mathrm{LN}$ patients were analyzed via univariate analysis, and results manifested that adverse factors affecting the prognosis of LN patients included age, hemoglobin, platelet, blood uric acid, urinary protein, IL-17 and IL-34, displaying statistically significant differences $(\mathrm{P}<0.05)$. According to results of multivariate Cox regression analysis, age, hemoglobin, blood uric acid, urinary protein, IL-17 and IL-34 were independent risk factors for poor prognosis of LN, and differences were statistically significant $(\mathrm{P}<0.05)$. Research results of Shen et al (21) revealed that there is a certain correlation between pathological types and clinical manifestations and prognosis of LN patients. Daniel et al (22) thought that influencing factors for prognosis of LN patients include age, decline in complement 3 , increase in urinary protein, decrease in hemoglobin and blood platelet, and increase in uric acid level, which are basically consistent with the results in this study. There will be changes in structure and function of both kidneys with age. Urinary protein can reflect glomerular lesion and damage, and increase the expression of inflammatory factors, thus leading to renal damage. At the same time, the increase in urinary protein results in a lower level of hemoglobin (23). In $\mathrm{LN}$, the renal tubule and interstitium can be damaged, leading to decline in erythropoietin, and IL-1 can be increased, leading to inhibited production of erythropoietin (24). High-level uric acid can aggravate renal hypertension, lead to glomerular autoregulation dysfunction and promote production of nitric oxide, thereby causing excretion disorder (25). In addition,
Wu et al (26) and Zhao et al (12) studied and found that the levels of IL-17 and IL-34 are positively correlated with urinary protein, and these levels can reflect the severity of LN, indicating that the disease condition and clinical manifestations of LN patients is gradually aggravated with the increase in levels of serum IL-17 and IL-34.

In conclusion, IL-17 and IL-34 are highly expressed in serum of LN patients. Results of univariate and multivariate Cox regression analyses reveal that age, hemoglobin, blood uric acid, urinary protein, IL-17 and IL-34 are independent risk factors for poor prognosis of LN. Studies on IL-17 and IL-34 provide broader ideas for clinical diagnosis, treatment and prognosis prediction of $\mathrm{LN}$, displaying a bright prospect.

\section{Acknowledgements}

Not applicable.

\section{Funding}

No funding was received.

\section{Availability of data and materials}

The datasets used and/or analyzed during the present study are available from the corresponding author on reasonable request.

\section{Authors' contributions}

YC and XY drafted the manuscript. YC, XY and XZ were mainly devoted to collecting and interpreting the data. $\mathrm{XZ}$ and ZA detected IL-17 and IL-34. All authors read and approved the final manuscript.

\section{Ethics approval and consent to participate}

The study was approved by the Ethics Committee of Yanan University Affiliated Hospital (Yanan, China). Signed informed consents were obtained from the patients or the guardians.

\section{Patient consent for publication}

Not applicable. 


\section{Competing interests}

The authors declare that they have no competing interests.

\section{References}

1. Rönnblom L and Pascual V: The innate immune system in SLE: Type I interferons and dendritic cells. Lupus 17: 394-399, 2008.

2. Mackay M, Stanevsky A, Wang T, Aranow C, Li M, Koenig S, Ravetch JV and Diamond B: Selective dysregulation of the FcgammaIIB receptor on memory B cells in SLE. J Exp Med 203: 2157-2164, 2006.

3. Faurschou M, Starklint H, Halberg P and Jacobsen S: Prognostic factors in lupus nephritis: Diagnostic and therapeutic delay increases the risk of terminal renal failure. J Rheumatol 33: 1563-1569, 2006.

4. Bajaj S, Albert L, Gladman DD, Urowitz MB, Hallett DC and Ritchie S: Serial renal biopsy in systemic lupus erythematosus. J Rheumatol 27: 2822-2826, 2000.

5. Ramos-Casals M, Nardi N, Lagrutta M, Brito-Zerón P, Bové A, Delgado G, Cervera R, Ingelmo $M$ and Font J: Vasculitis in systemic lupus erythematosus: Prevalence and clinical characteristics in 670 patients. Medicine (Baltimore) 85: 95-104, 2006.

6. Heimovski FE, Simioni JA and Skare TL: Systemic lupus erythematosus and Raynaud's phenomenon. An Bras Dermatol 90 837-840, 2015.

7. D'Cruz DP, Mellor-Pita S, Joven B, Sanna G, Allanson J, Taylor J, Khamashta MA and Hughes GR: Transverse myelitis as the first manifestation of systemic lupus erythematosus or lupus-like disease: Good functional outcome and relevance of antiphospholipid antibodies. J Rheumatol 31: 280-285, 2004.

8. Lin H, Lee E, Hestir K, Leo C, Huang M, Bosch E, Halenbeck R, Wu G, Zhou A, Behrens D, et al: Discovery of a cytokine and its receptor by functional screening of the extracellular proteome. Science 320: 807-811, 2008.

9. Foucher ED, Blanchard S, Preisser L, Garo E, Ifrah N, Guardiola P, Delneste Y and Jeannin P: IL-34 induces the differentiation of human monocytes into immunosuppressive macrophages. antagonistic effects of GM-CSF and IFN $\gamma$. PLoS One 8: e56045, 2013.

10. Chalmers SA, Chitu V, Ramanujam M and Putterman C: Therapeutic targeting of macrophages in lupus nephritis. Discov Med 20: 43-49, 2015 .

11. Roussel L, Houle F, Chan C, Yao Y, Bérubé J, Olivenstein R, Martin JG, Huot J, Hamid Q, Ferri L, et al: IL-17 promotes p38 MAPK-dependent endothelial activation enhancing neutrophil recruitment to sites of inflammation. J Immunol 184: 4531-4537, 2010.

12. Zhao XF, Pan HF, Yuan H, Zhang WH, Li XP, Wang GH, Wu GC, $\mathrm{Su} \mathrm{H}$, Pan FM, Li WX, et al: Increased serum interleukin 17 in patients with systemic lupus erythematosus. Mol Biol Rep 37: 81-85, 2010.

13. Hsu HC, Yang P, Wang J, Wu Q, Myers R, Chen J, Yi J, Guentert T, Tousson A, Stanus AL, et al: Interleukin 17-producing T helper cells and interleukin 17 orchestrate autoreactive germinal center development in autoimmune BXD2 mice. Nat Immunol 9: $166-175,2008$
14. Sprangers B, Monahan M and Appel GB: Diagnosis and treatment of lupus nephritis flares - an update. Nat Rev Nephrol 8: 709-717, 2012.

15. Mok CC, Ying KY, Tang S, Leung CY, Lee KW, Ng WL, Wong RW and Lau CS: Predictors and outcome of renal flares after successful cyclophosphamide treatment for diffuse proliferative lupus glomerulonephritis. Arthritis Rheum 50: 2559-2568, 2004

16. Saxena R, Mahajan T and Mohan C: Lupus nephritis: Current update. Arthritis Res Ther 13: 240, 2011.

17. Balow JE, Waldman M and Austin HA (eds): Lupus nephritis. In: Therapy in Nephrology \& Hypertension. Saunders, Philadelphia, PA, pp157-171, 2008.

18. Bethunaickan R, Berthier CC, Zhang W, Kretzler M and Davidson A: Comparative transcriptional profiling of 3 murine models of SLE nephritis reveals both unique and shared regulatory networks. PLoS One 8: e77489, 2013.

19. Susianti H, Iriane VM, Dharmanata S, Handono K, Widijanti A, Gunawan A and Kalim H: Analysis of urinary TGF- $\beta 1$, MCP-1, NGAL, and IL-17 as biomarkers for lupus nephritis. Pathophysiology 22: 65-71, 2015.

20. Menke J, Rabacal WA, Byrne KT, Iwata Y, Schwartz MM, Stanley ER, Schwarting A and Kelley VR: Circulating CSF-1 promotes monocyte and macrophage phenotypes that enhance lupus nephritis. J Am Soc Nephrol 20: 2581-2592, 2009.

21. Shen K, Yu Y, Tang Z, Liu Z and Li L: The prognosis of biopsyproven lupus nephritis in Chinese patients: Long term follow-up of 86 cases. Chin Med J (Engl) 110: 502-507, 1997.

22. Daniel L, Sichez H, Giorgi R, Dussol B, Figarella-Branger D, Pellissier JF and Berland Y: Tubular lesions and tubular cell adhesion molecules for the prognosis of lupus nephritis. Kidney Int 60: 2215-2221, 2001 .

23. Nee R, Jindal RM, Little D, Ramsey-Goldman R, Agodoa L, Hurst FP and Abbott KC: Racial differences and income disparities are associated with poor outcomes in kidney transplant recipients with lupus nephritis. Transplantation 95: 1471-1478, 2013.

24. Yap DY, Tang CS, Ma MK, Lam MF and Chan TM: Survival analysis and causes of mortality in patients with lupus nephritis. Nephrol Dial Transplant 27: 3248-3254, 2012.

25. Sánchez-Lozada LG, Tapia E, López-Molina R, Nepomuceno T, Soto V, Avila-Casado C, Nakagawa T, Johnson RJ, HerreraAcosta $\mathrm{J}$ and Franco M: Effects of acute and chronic L-arginine treatment in experimental hyperuricemia. Am J Physiol Renal Physiol 292: F1238-F1244, 2007.

26. Wu T, Fu Y, Brekken D, Yan M, Zhou XJ, Vanarsa K, Deljavan N, Ahn C, Putterman C and Mohan C: Urine proteome scans uncover total urinary protease, PGDS, SAP and SOD as potential markers of lupus nephritis. J Immunol 184: 2183-2193, 2010.

This work is licensed under a Creative Commons Attribution-NonCommercial-NoDerivatives 4.0 International (CC BY-NC-ND 4.0) License. 